\title{
EFFECT OF DIFFERENT TYPES AND CONCENTRATION OF ROOTING HORMONES ON Momordica cochinensis (GAC FRUIT) ROOT VINE CUTTINGS
}

\author{
AZIMAH HAMIDON ${ }^{1,2}$, RAMISAH M. SHAH ${ }^{1 *}$, RAZIFAH MOHD RAZALI $^{3}$ and SUHAIZAN LOB ${ }^{1}$ \\ ${ }^{1}$ Faculty of Fisheries and Food Science, University Malaysia Terengganu, \\ 21030, Kuala Terengganu, Terengganu, Malaysia \\ ${ }^{2}$ Agricultural Science Department, Faculty of Technical and Vocational, \\ Universiti Pendidikan Sultan Idris, 35900 Tanjung Malim, Perak \\ ${ }^{3}$ Faculty of Science and Marine Environment, University Malaysia Terengganu, \\ 21030 Kuala Terengganu, Terengganu, Malaysia \\ *E-mail: ramisah@umt.edu.my
}

Accepted 16 November 2020, Published online 25 December 2020

\begin{abstract}
Momordica cochinchinensis (Gac fruit) grows as perennial climbers and dioecious plants, where it can be cultivated from seeds, root tubers, and root vine cuttings. Rooted vine cuttings are more reliable than seed propagation, which can be affected by dormancy and delay production. The application of auxin group of hormones such as Indole acetic acid (IAA), Indole-3butyric acid (IBA), and Naphthaleneacetic acid (NAA) in certain concentrations shown good results in inducing root initiation faster and effective. However, experimental data and information on the plant growth hormone application on M. cochinchinensis vine cuttings propagation are not very extensive, especially in Malaysia. Thus, the objective of this study was to determine the effect of different concentrations of IAA, IBA, and NAA on $M$. cochinchinensis vine cutting propagation. The design of the experiment is a randomized complete block design in a factorial experiment, with five replications. The treatments comprised three types of plant growth hormone, IAA, IBA, and NAA with 0, 500, 1000, and $3000 \mathrm{ppm}$ concentrations. Data recorded were surviving rate or percentage of rooting, root numbers per rooted cutting, means of root length, length of longest root, total root length per rooted cuttings, sprouting percentage, and sprouting length. The vine cutting treated with IBA and NAA $1000 \mathrm{ppm}$ has shown a considerably positive effect in root formation and sprouting.
\end{abstract}

Key words: Rooted vine cutting, dieocious, rooting formation, surviving rate, sprouting

\section{INTRODUCTION}

Gac fruit, Momordica cochinchinensis Spreng is one of the underutilized species of the Cucurbitaceae family (Joseph \& Bharathi, 2008). Gac fruit is a large, bright red fruit (Kuhnlein, 2004) that also known as 'the fruit from heaven' in South-East Asia (Voung et al., 2006), due to its acclaimed properties in enhancing longevity, vigour, and vitality. Momordica cochinchinensis is a perennial vine climber and produces up to 60 fruits weighing 1-3 $\mathrm{kg}$ each in one season (Shadeque \& Baruah, 1984; Muchjajib \& Muchjajib, 2013). Recent studies showed that this fruit had a high carotenoid content, especially lycopene and Beta-carotene. The M. cochinchinensis aril has natural levels of

\footnotetext{
* To whom correspondence should be addressed.
}

lycopene about five times the concentration of that found in tomatoes (Vuong, 2000). There is great potential that $M$. cochinchinensis could be promoted as a highly nutritious fruit. Cultivation of the underutilized M. cochinchinensis would potentially improve livelihoods and could meet the increasing demand for M. cochinchinensis as a health product.

The $M$. cochinchinensis can be cultivated from seeds or root tubers and grows as dioecious vines that are separate male and female plants (Vuong, 2000). Rooted vine cuttings can also be used for propagation and are more reliable than production from seeds, which can be affected by dormancy and a long lead time into production. One issue for seedling production is that the plant gender can only be identified when flowers develop (Parks et al., 2013), as recent techniques of gender identification 
of seed using DNA technology are still in their infancy (Sarkar et al., 2017). Two to three node cuttings from $M$. cochinchinensis vine give better rooting, plant growth, and yield (Ram et al., 2002). However, the cuttings should be taken from vigorously growing mother plants at the early flowering stage and before axillary flower buds emerge. Though many workers have mentioned seed dormancy as the main factor limiting the cultivation of spine gourds (Ram et al., 2001) and proposed rooted vine cuttings as an alternative propagation tool, there are no reports on the ratooning behavior of such propagules. The application with plant growth hormone on mid and top-level cuttings showed positive results in inducing roots on $M$. cochinchinensis vine cutting (Joseph \& Bharathi, 2008).

Cuttings of some species root readily without an auxin treatment, while cuttings of other species benefit from auxin treatment through the enhanced promotion of rooting; benefits may be dependent upon the species and cultivar, type of plant hormones used, environment condition during cutting propagation, time of year, and other factors (Griffith, 1998, Hartmann et al., 2002). Altering hormonal activity within a plant using plant growth hormones has been proved to positively improve plant germination, growth, and development (Hopkins \& Hüner, 2004). The factors that control plant growth behavior in response to plant growth hormones include the type of plant, type of stimulant, amount of stimulant applied, the timing of application, stage of growth, and location of stimulant application (Kambaska \& Santilata, 2009). It is widely common to use growth regulators (hormones) for inducing root formation and application to the bottom of the cuttings almost always results in faster and more rooting. Indole-3butyric acid (IBA) is considered the best artificial hormone used because it is nontoxic to plants over a wide range of concentrations. However, the application of other hormones, too, has given good results such as indole acetic acid (IAA) and naphthaleneacetic acid (NAA) (Ludwig-Müller et al., 2005; Isfendiyarolu \& Ozeker et al., 2009) and Indole-3-butyric acid (IBA).

Since growth by seedling takes time to germinate, the cutting propagation technique could fasten the growth and produce fruits early (Duke \& duCellier, 1993). Auxin is a common and prevalent phytohormone used in stem cutting propagation of tree species to promoting adventitious roots (Kesari et al., 2009). Although IAA, IBA, and NAA were proven effective in promoting rooting depends on plant species (Kesari et al., 2009) however there has been no report on the rooting performance of $\mathrm{M}$. cochinchinensis vine cutting. Thus, the objective of this study was to determine the effect of different concentrations of Indole-3-acetic acid (IAA), Indole3-butyric acid (IBA), and naphthaleneacetic acid (NAA) hormone treatments on $M$. cochinchinensis vine root cutting propagation.

\section{MATERIALS AND METHODS}

The study was conducted in the Tapak Semaian Universiti Malaysia Terengganu (UMT). A high humidity environment $(60-80 \% \mathrm{RH})$ with $50 \%$ shade was provided in the propagation area where the intermittent mist was supplied for 15 min twice a day, at 8.00 am and 3.00 pm every day. The stock plant at Ladang 10, University Putra Malaysia was used as planting material. Cuttings with two nodes were taken between 15 and $20 \mathrm{~cm}$ in length with a basal diameter of between 3 and $6 \mathrm{~mm}$. On each cutting, one leaf was retained and cut in half. The base of the cutting was cut diagonally with a scalpel to ensure a clean wound. Cuttings were dipped into Indole-3-acetic acid (IAA), Indole-3-butyric acid (IBA), and naphthaleneacetic acid (NAA) hormone treatments with 4 levels of concentrations $(0,500$, 1000 , and $3000 \mathrm{ppm})$. The controls were not treated with the hormone. Each of these three treatments was replicated 12 times, in 12 polybags for each treatment. The media type used in polybag is a potting mix (2:1:1 topsoil: sand: peat moss). The cuttings were placed in a propagation greenhouse and watered with overhead sprinklers.

The experiment was conducted using the randomized complete block design, arranged in a factorial experiment, with five replications. The treatments comprised three types of rooting hormone, i) Indole-3-acetic acid (IAA), Indole-3butyric acid (IBA), and naphthaleneacetic acid $($ NAA $) \times 4$ levels of concentrations $(0,500,1000$, and $3000 \mathrm{ppm}$ ) applied on M. cochinchinensis cuttings. Data were analyzed using the analysis of variance (ANOVA), and significant treatment means were separated by Duncan's multiple range test (DMRT) at $p<0.05$ (SAS, version 9.3).

Data were taken after 5 weeks for surviving rate or percentage of rooting (the number of rooted cuttings divide by total planted cuttings and multiply with 100), root numbers per rooted cutting (the number of roots divide by total rooted cuttings), means of root length $(\mathrm{cm})$ per rooted cutting (total root length divide by total rooted cuttings), length of longest root, total root length per rooted cuttings, sprouting percentage, sprouting length and root dry weight $(\mathrm{g})$ per rooted cutting (total dry weight divide by total rooted cuttings). Cuttings with an adventitious root measured $3 \mathrm{~mm}$ in length were considered rooted. 


\section{RESULTS AND DISCUSSION}

There was a significant interaction effect between plant growth hormone and concentrations on surviving rate, several roots, and sprouting percentage of $M$. cochinchinensis root vine cuttings (Table 1). Thus, the results and discussion would focus on the relationship between the surviving rate, the number of roots and sprouting percentage, and concentrations of each hormone (IAA, IBA, and NAA). However, there was no significant relationship between surviving rate, number of roots, and sprouting percentage with 4 levels of concentrations. On the other hand, there was no significant interaction effect between three types of plant growth hormone and 4 concentrations levels on longest root length, total root length means of root length, and shoot length of $M$. cochinchinensis root vine cuttings (Table 1). The highest surviving rate showed in Figure 1a are M. cochinchinensis root vine cuttings treated with IBA and NAA 1000 ppm, where the surviving rate for both treatments is $95.8 \%$. The optimal plant growth hormone used for propagation according to the highest surviving rate are IBA and NAA 1000 ppm for M. cochinchinensis root vine cutting. Rooting of cuttings could be increased after treated with IBA, NAA, or a combination of the two (Blythe et al., 2004). However, a study by Parks et al. (2013), showed that the survival of $M$. cochinchinensis cuttings improves from 53 to $77 \%$ with IBA 3000 to $5000 \mathrm{ppm}$.

Root vine cuttings treated with IAA and NAA $3000 \mathrm{ppm}$, and NAA $500 \mathrm{ppm}$ showed the highest number of roots. Approximately higher by 54 to
$63 \%$ number of roots than control (Figure 1b). However, there were no significant differences between control and root vine cuttings treated with IBA $1000 \mathrm{ppm}$ and $3000 \mathrm{ppm}$ and IAA $3000 \mathrm{ppm}$. This could be because a longer period is required for IBA to induce rooting compared to IAA or NAA (Krisanthini et al., 2006). It was also shown in Table 1 that the total root length of vine cutting treated with 500, 1000 and 3000 ppm of the hormone were $31 \%$ to $42.3 \%$ higher than control. The reason $M$. cochinchinensis vine root cutting treated with IAA had a lower surviving rate than IBA might be because it breaks down quickly in the plant.

The highest sprouting percentages were root vine cuttings treated with IBA and NAA $1000 \mathrm{ppm}$, 90 to $93 \%$ sprouting respectively (Figure $2 \mathrm{c}$ ). Both treatments also were not significantly different with vine root cuttings treated with IBA $500 \mathrm{ppm}$ where it showed $83 \%$ sprouting (Figure 1c). In contrast, the lowest sprouting showed in this study was root vine cuttings treated with NAA 500 ppm, with $61.1 \%$ sprouting (Figure 2c). Sprouting percentages have a similar graph trend with surviving rates. In Table 1 , vine root cutting treated with IAA, IBA, and NAA $1000 \mathrm{ppm}$ showed a higher sprouting percentage with IBA is higher than IAA and NAA by $9.4 \%$ and $8 \%$, respectively.

Momordica cochinchinesis vine root cuttings treated with IBA and NAA showed some improvement in rooting and shooting percentage. Auxins have a significant role in adventitious root development on cuttings by promoting lateral roots initiation and enhanced the transport of

Table 1. Main and interaction effects of different types of hormone and concentration (0, 500, 1000, and 3000 ppm) on the surviving rate, number of roots, longest root length, total root length, mean root length, sprouting percentage and shoot length of Momordica cochinchinensis root vine cuttings

\begin{tabular}{lccccccc}
\hline Factor & $\begin{array}{c}\text { Surviving } \\
\text { rate } \\
(\%)\end{array}$ & $\begin{array}{c}\text { Number } \\
\text { of } \\
\text { roots }\end{array}$ & $\begin{array}{c}\text { Longest } \\
\text { root length } \\
(\mathrm{cm})\end{array}$ & $\begin{array}{c}\text { Total root } \\
\text { length } \\
(\mathrm{cm})\end{array}$ & $\begin{array}{c}\text { Means root } \\
\text { length } \\
(\mathrm{cm})\end{array}$ & $\begin{array}{c}\text { Sprouting } \\
\text { percentage } \\
(\%)\end{array}$ & $\begin{array}{c}\text { Shoot } \\
\text { length } \\
(\mathrm{cm})\end{array}$ \\
\hline $\begin{array}{l}\text { Hormone (H) } \\
\text { IAA }\end{array}$ & & & & & & & \\
IBA & $78.13^{\mathrm{b}}$ & $21.8^{\mathrm{ab}}$ & $22.57^{\mathrm{a}}$ & $209.6^{\mathrm{ab}}$ & $10.57^{\mathrm{a}}$ & $75.0^{\mathrm{b}}$ & $25.87^{\mathrm{a}}$ \\
NAA & $87.85^{\mathrm{a}}$ & $17.5^{\mathrm{b}}$ & $24.27^{\mathrm{a}}$ & $177.65^{\mathrm{b}}$ & $10.74^{\mathrm{a}}$ & $84.4^{\mathrm{a}}$ & $27.08^{\mathrm{a}}$ \\
\hline Concentrations (C) (ppm) & $80.56^{\mathrm{b}}$ & $23.7^{\mathrm{a}}$ & $22.69^{\mathrm{a}}$ & $222.43^{\mathrm{a}}$ & $10.42^{\mathrm{a}}$ & $76.4^{\mathrm{b}}$ & $19.53^{\mathrm{a}}$ \\
$\quad$ & & & & & & & \\
0 & $79.17^{\mathrm{b}}$ & $12.33^{\mathrm{c}}$ & $24.38^{\mathrm{a}}$ & $137.78^{\mathrm{b}}$ & $11.43^{\mathrm{a}}$ & $75.0^{\mathrm{b}}$ & $16.00^{\mathrm{b}}$ \\
500 & $79.63^{\mathrm{b}}$ & $25.72^{\mathrm{a}}$ & $23.64^{\mathrm{a}}$ & $236.53^{\mathrm{a}}$ & $9.90^{\mathrm{a}}$ & $76.38^{\mathrm{b}}$ & $18.83^{\mathrm{b}}$ \\
1000 & $88.43^{\mathrm{a}}$ & $19.17^{\mathrm{b}}$ & $23.78^{\mathrm{a}}$ & $199.73^{\mathrm{a}}$ & $11.28^{\mathrm{a}}$ & $84.73^{\mathrm{a}}$ & $31.86^{\mathrm{a}}$ \\
\hline 000 & $81.48^{\mathrm{b}}$ & $26.83^{\mathrm{a}}$ & $20.89^{\mathrm{a}}$ & $238.85^{\mathrm{a}}$ & $9.69^{\mathrm{a}}$ & $78.24^{\mathrm{b}}$ & $29.93^{\mathrm{a}}$ \\
\hline
\end{tabular}

Significance

\begin{tabular}{lllllll}
\hline Hormone $(\mathrm{H})$ & $*$ & $\mathrm{~ns}$ & $\mathrm{~ns}$ & $\mathrm{~ns}$ & $\mathrm{~ns}$ & * \\
\hline Concentrations $(\mathrm{C})$ & $*$ & $*$ & $\mathrm{~ns}$ & $*$ & * & \\
\hline $\mathrm{H} \times \mathrm{C}$ & $*$ & $*$ & $\mathrm{~ns}$ & $\mathrm{~ns}$ & $\mathrm{~ns}$ & ns \\
\hline
\end{tabular}

* Significant at $p \leq 0.05$. 


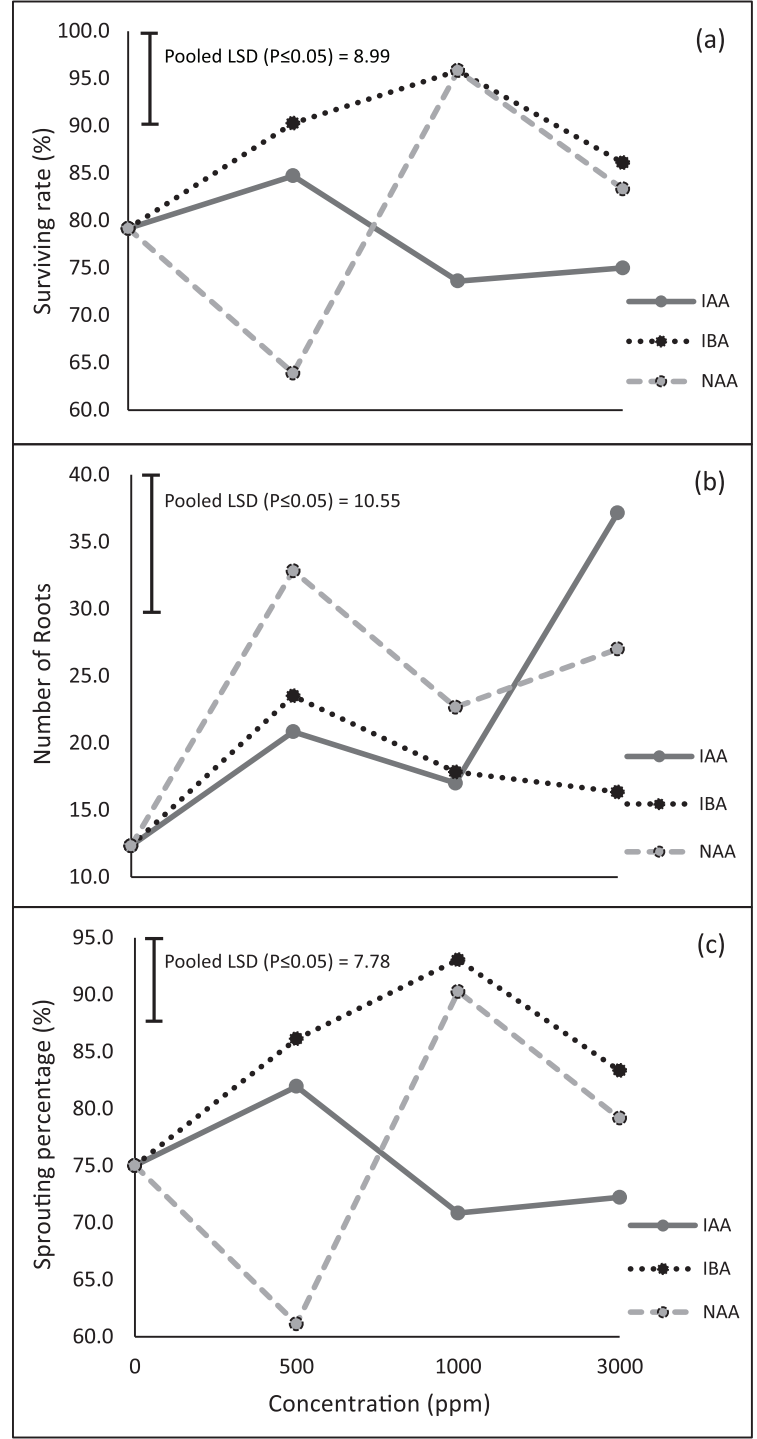

Fig. 1. Surviving rates (a), number of roots (b), and sprouting percentages (c) of $M$. cochinchinensis vine cuttings treated with 4 concentration levels of IAA, IBA, and NAA. $(\mathrm{n}=6)$.

carbohydrates to the basal portion of the cuttings (Stefan \& Rasmussen, 2016). Optimum endogenous and exogenous auxin levels could lead to successful adventitious root formation and the development of cuttings (Ludwig-Müller, 2000; Kochhar et al., 2005). Synthetic auxin application on cuttings such as IBA can increase rooting percentage and number of adventitious roots per rooted cutting (Patricio et al., 2006; Kesari et al., 2009; Lemay et al., 2009) since it is non-toxic to plants over a wide range of concentration (Hartmann et al., 2002). However, exogenous IBA may improve rooting up until a certain con-centration, since higher IBA concentration may become toxic (Titon et al., 2003;
Rambaran, 2013). Therefore, it is important to configure the optimum concentration for $M$. cochinchinesis vine root cutting. According to Kesari et al., (2009), the effectiveness in adventitious root formation was in the order of IBA $>$ NAA $>$ IAA when applied singly in Pongamia pinnata.

The process of adventitious root formation is influenced by several internal and external factors. Among the internal factors, the most important role is ascribed to phytohormones, especially the auxins. It is generally accepted that auxins have a certain role in rooting initiation (Stefancic et al., 2005). Auxins control growth and development in plants, including lateral root initiation and root gravity response. Many studies have shown that exogenous application of auxins results in increased initiation of lateral roots and that lateral root development is highly dependent on auxin and auxin transport (Chhun et al., 2003). This study has established that a more-efficient, larger-scale propagation system for $M$. cochinchinensis is possible using cuttings propagation techniques. Few resources will be required to achieve these greater efficiencies and could be implemented in regional areas to take advantage of local genetic diversity in $M$. cochinchinensis, more likely to be suited to the local growing conditions (Sthapit et al., 2008).

\section{CONCLUSION}

This study effectively distinguishes the application of plant growth hormones with four concentration levels on vine propagation cutting. The concentration and plant growth hormone recommended would be IBA and NAA $1000 \mathrm{ppm}$ since the cuttings showed significant results in improving the surviving rate and sprouting percentages, which are higher than $90 \%$. This showed that NAA and IBA have more effect on stimulating adventitious roots than naturally occurring or synthetic IAA. Further research should be carried out on different cutting types, media, and environment to achieve greater impact of productivity and higher surviving rate.

\section{ACKNOWLEDGEMENT}

We would like to acknowledge the Crop Science Department, Faculty of Fisheries and Food Science, Universiti Malaysia Terengganu for providing the facilities to conduct this study. We also thank Prof. Dr. Mohamad bin Osman for his expertise and assistance in providing the material for this study. 


\section{REFERENCES}

Blythe, B.K., Sibley, J.L., Ruter, J.M. \& Tilt, K.M. 2004. Cutting propagation of foliage crop using a foliar application of auxin. Scientia Horticulturae, 103(1): 31-37.

Chhun, T., Taketa, S., Tsurumi, S. \& Ichii, M. 2003. The effects of auxin on lateral root initiation and root gravitropism in a lateral rootless mutant Lrt1 of rice (Oryza sativa L.). Plant Growth Regulation, 39(2): 161-170.

Duke, J.A. \& duCellier, J.L. 1993. CRC Handbook of Alternative Cash Crops. CRC Press, Boca Raton, Florida. 536 pp.

Griffin, A.R., Burgess, I.P. \& Wolf, L. 1988. Patterns of natural and manipulated hybridisation in the genus Eucalyptus L'hérit. 1 A Review. Australian Journal of Botany, 36(1): 41-66.

Hartmann, H.T., Kester, D.E., Davies, Jr. F.T. \& Geneve, R.L. 2002. Plant Propagation: Principles and Practices. $7^{\text {th }}$ Ed. Pearson Education Inc., Upper Saddle River, New Jersey.

Hopkins, W.G. \& Hüner, N.P. 2004. Introduction to Plant Physiology. $3^{\text {rd }}$ Ed. John Wiley and Sons Inc, New Jersey. p. 560.

Isfendiyarolu, M. \& Ozeker, E. 2009. Rooting of 'Ayvalik' olive cuttings in different media. Spanish Journal of Agricultural Research, 7(1): 165-172.

Joseph, J.K. \& Bharathi, L.K. 2008. Sweet Gourd (Momordica cichinchinensis (Lour) Spreng). Underutilized and Underexploited Horticultural Crops, 4: 185-191.

Kambaska, K.B. \& Santilata, S. 2009. Effect of plant growth regulator on micropropagation of ginger (Zingiber officinale Rosc.) cvSuprava \& Suruchi. Journal of Agricultural Technology, 5(2): 271-280.

Kesari, V., Krishnamachari, A. \& Rangan, L. 2009. Effect of auxins on adventitious rooting from stem cuttings of candidate plus tree Pongamia pinnata (L.), a potential biodiesel plant. Trees, 23(3): 597-604.

Kochhar, S., Kochhar, V.K., Singh, S.P., Katiyar, R.S. \& Pushpangadan, P. 2005. Differential rooting and sprouting behaviour of two Jatropha species and associated physiological and biochemical changes. Current Science, 89(6): 936-939.

Krisantini, S., Johnston, M., Williams, R.R. \& Beveridge, C. 2006. Adventitious root formation in Grevillea (Proteaceae), an Australian native species. Scientia Horticulturae, 107(2): 171175.

Kuhnlein, H.V. 2004. Karat, pulque, and $M$. cochinchinesis: Three shining stars in the traditional food galaxy. Nutrition Reviews, 62(11): 439-442.
Lemay, V., Gâteblé, G. \& McCoy, S. 2009. Vegetative propagation of two endemic species of Cloezia Brongn. \& Gris for conservation and mining revegetation activities in New Caledonia. New Forests, 37(1): 1-8.

Ludwig-Müller, J., 2000. Indole-3-butyric acid in plant growth and development. Plant Growth Regulation, 32(2-3): 219-230.

Muchjajib, S. \& Muchjajib, U. 2013. The development of a production system and postharvest handling for Gac Fruit (Momordica cochinchinensis): Knowledge transfer to a community enterprise in Thailand, in: VI International Conference on Managing Quality in Chains. Cranfield, United Kingdom, pp. 63-66.

Parks, S.E., Murray, C.T., Gale, D.L., Al-Khawaldeh, B. \& Spohr, L.J. 2013. Propagation and production of $M$. cochinchinesis (Momordica cochinchinensis Spreng.), a greenhouse case study. Experimental Agriculture, 49(2): 234243.

Patricio, H.P., Castaneto, Y.T., Vallesteros, A.P. \& Castaneto, E.T. 2006. Macropropagation of Shorea guiso using stem cuttings. Journal of Tropical Forest Science, 18(3): 198-201.

Ram, D., Banerjee, M.K. \& Kalloo, G. 2002. Popularizing kakrol and kartoli: The indigenous vegetables. Indian Horticulture, 47(3): 6-9.

Ram, D., Banerjee, M.K., Pandey, S. \& Srivastava, U. 2001. Collection and evaluation of Kartoli (Momordica dioica Roxb. Ex. Willd.). Indian Journal of Plant Genetic Resources, 14(2): 114116.

Rambaran, N. 2013. Survival and Rooting of Selected Vegetatively Propagated Eucalyptus Clones in Relation to Supplied Auxin (Ph.D). University of KwaZulu-Natal, Durban.

Sarkar, S., Banerjee, J. \& Gantait, S. 2017. Sexoriented research on dioecious crops of Indian subcontinent: An updated review. Biotech, 7(2): 93.

Shadeque, A. \& Baruah, G.K.S. 1984. Sweet gourd: a popular vegetable of Assam. Indian Farmin, 34(8): 25-35.

Stefans, B. \& Rasmussen, A. 2016. The physiology of adventitious roots. Plant Physiology, 170(2): 603-617.

Stefancic, M., Stampar, F. \& Osterc, G. 2005. Influence of IAA and IBA on root development and quality of Prunus' GiSelA 5'leafy cuttings. HortScience, 40(7): 2052-2055.

Sthapit, B., Rana, R., Eyzaguirre, P. \& Jarvis, D. 2008. The value of plant genetic diversity to resource-poor farmers in Nepal and Vietnam. International Journal of Agricultural Sustainability, 6(2): 148-166. 
Titon, M., Xavier, A., Otoni, W.C. \& Motoike, S.Y. 2007. Effect of dicamba and picloram growth regulators on somatic embryogenesis in Eucalyptus grandis. Tree Magazine, 31(3): 417426.

Vuong, L.T. 2000. Underutilized $\beta$-carotene - rich crops of Vietnam. Food and Nutrition Bulletin, 21(2): 173-181.
Vuong, L.T., Franke, A.A., Custer, L.J. \& Murphy, S.P. 2006. Momordica cochinchinensis Spreng. (M. cochinchinesis) fruit carotenoids reevaluated. Journal of Food Composition and Analysis, 19(6-7): 664-668. 